\title{
Impacts of Microfinance Programs in Thailand
}

\author{
$\underline{\text { W. Hemtanon }}^{\text {a }}$ and C. Gan ${ }^{\text {a }}$ \\ ${ }^{a}$ Faculty of Agribusiness and Commerce, Department of Financial and Business Systems, Lincoln University, \\ New Zealand \\ Email: wittawat.hemtanon@lincolnuni.ac.nz
}

\begin{abstract}
Thailand has been developing its economy based on national and social-development plans over the last six decades. These plans focus on economic growth by supporting the manufacturing industry in order to export products to other countries. As a result, the growth rate performance has been outstanding since the late 1950s. Moreover, the Thai economy had been one of the fastest-growing economies in the world, and the GDP grew 10 per cent per year in the 1990s (Warr, 2000). Poverty incidence has thus declined dramatically. However, income inequality is still a big problem in Thailand. TDRI (2004) and Bird, et al. (2011) suggest that microfinance can assist to reduce income inequality among the poor. Under the Thailand National Economic and Social Development Plan (NESDP), microfinance institutions (MFIs) are considered to play an important role to enable poor people to equally access financial resources and new financial products at reasonable cost (Tambunlertchai, 2015).

This paper evaluates the impacts of microfinance programs on economic and social welfare of households in Thailand. The study employs secondary data from the Socioeconomic Survey (cross-sectional data in 2017 and panel data in 2012 and 2017) to evaluate the impact of the MFIs. The estimation methods include propensity score matching (PSM) and a fixed effect (FE) model.

The result shows the impacts of Village Funds (VFs) are significant in terms of income and expenditure but not on housing, food, and medical expenditures. However, the impacts of VFs are negative. In terms of Saving Groups for Production (SGPs), the empirical results reveal that SGPs effects are significant in income but insignificant in expenditure. The FE model result also shows that VF impacts only education expenditure, but impacts on income and transport expenditure of SGPs.
\end{abstract}

Keywords: Poverty, Microfinance institutions, Village Funds, Saving Groups 


\section{INTRODUCTION}

Over the past six decades, Thailand has been developing its economy based on national and social development plans. These plans have encouraged economic growth by supporting the manufacturing industry, with the aim of increasing exports to other countries. As a result, the Thai economy is one of the fastest-growing economies in the world: GDP grew $10 \%$ per year in the 1990s (Warr, 2000). Poverty rates have dramatically declined, from $65.17 \%$ of the total population or 34.2 million people to $7.9 \%$ or 5.47 million between 1988 and 2017 (Asian Development Bank [ADB], 2019; Office of the National Economic and Social Development Board [NESDB], 2015; Warr, 2011). However, income inequality still remains a significant problem in Thailand. The Gini index shows changes between 1988 and 2017, from 0.487 to 0.365 , despite declining poverty rates over the same period (The World Bank [WB], 2019). Income inequality has become a national priority.

Thailand's Twelfth National Economic and Social Development Plan (12th NESDP) established in 2017 (and covers a five year period), showed that the overall development vision linked with the vision of the 20-year national strategy (2017-2036). This document outlines the 20-year vision: "Thailand as a developed country with security, prosperity, and sustainability in accordance with the principles of the Sufficiency Economy Philosophy" (NESDB 2017, p. 5). This vision will be achieved through ten core strategies. Significantly for this study, two of these strategies relates to financial inclusion. Under the strategy of creating a just society and reducing inequality, this strategy is designed to increase the productivity of the poorest sector of the population (set at $40 \%$ ): the lowest income group, the disadvantaged, women, and the elderly. This strategy also supports small and medium-sized enterprises (SMEs), community and social enterprises, the development of Microfinance Institutions (MFIs) and greater financial access for job-creation. All of these activities are deemed important for achieving inequality alleviation. MFIs play a vital role to help the poor households' access to financial services. The following section provides an overview of Thai MFIs.

\section{MICROFINANCE INSTITUTIONS (MFIS) IN THAILAND}

MFIs in Thailand can be divided into three main groups (Bird et al., 2011). The first group includes formal MFIs, such as banks and nonbanks institutions are controlled by prudential regulations. This group consists of commercial banks and special financial institutions (SFIs). The second group consists of semi-formal MFIs which are not controlled by prudential regulations. However, these institutions still have legal status (Tambunlertchai, 2015). The second group includes cooperatives, Saving Groups for Production (SGPs) and Village Funds (VFs). The last group covers informal MFIs which are not established or covered by government legislation. This group is smaller than the formal and semi-formal groups. They are often saving groups which operate at the village level (Bird et al., 2011; Tambunlertchai, 2015).

Studies have shown that in Thailand most low income and poor people can access financial services from community-based MFIs, such as VFs, cooperatives, and SGPs (Microfinance Services, Ltd., 2013; Suwaruchiporn, 2016). Therefore, these Thai MFIs play an important role in encouraging the poor to participate in financial services, which can ultimately help them to escape poverty. This study focuses on VFs and SGPs.

\subsection{Village Funds (VFs)}

The VF program, the largest government microfinance program in Thailand, was launched by the government in 2001. The Thai government provided THB 1 million (about USD 22,500 at the average exchange rate of USD $1=$ THB 44.5 in 2001) per village, to more than 77,000 villages and urban communities across the country (Fongthong \& Suriya, 2014). After the general election in 2011, the government increased funding to THB 2 million (about USD 65,800 at an average exchange rate of USD $1=$ THB 30.4 in 2011) per village. This program plays an important role in the credit market in Thailand, especially for the poor who live in rural areas and who are often unable to access formal financial services (Fongthong \& Suriya, 2014).

\subsection{Saving Groups for Production (SGPs)}

SGPs were established in 1974 by community leaders in order to encourage members to save. SGPs' involve gathering people with different status in the village to help each other to solve their investment problems (Luxchaigul, 2014).The local people regularly save money in their cash pool. Savings are the best way to fund accumulation (Luxchaigul, 2014). SGPs' economic activities begin with saving for welfare provision and loans. Borrowers obtain loans to invest their businesses (Luxchaigul, 2014). SGPs also provide loans to improve members' livelihoods and to deal with emergencies. SGPs play an important role in providing microfinance services to the poor (Meagher, 2013). 
This study investigates the impact of microfinance programs on the economic and social welfare of households in Thailand. It is important to understand the impact of microfinance programs because these results are a crucial step towards developing effective microfinance products and services which can help reduce poverty problems (Cintina \& Love, 2014).

\section{DATA COLLECTION METHOD}

The current study uses cross-sectional data (2017) and panel data from the Socioeconomic Survey (SES) (2012 and 2017) to evaluate the accessibility and impact of VFs and SGPs on Thai households. Cross-sectional data is obtaibed from the SES Survey (2017), collected by the National Statistical Office, from the Ministry of Information and Communication Technology. The survey interviewed 43,210 households (both borrowers and non-borrowers) across the country. Data was collected monthly. The information includes a variety of household socioeconomic data, including household income, expenses, assets, and liabilities.

Panel data from the SES surveys in 2012 and 2017, was collected by the National Statistical Office and the Ministry of Information and Communication Technology. The 2017 survey interviewed 4,461 households across the country. Data was collected monthly. The information includes a variety of household socioeconomic data, such as household income, expenses, assets, and liabilities. The 2012 survey utilized the same questionnaire and covered 6,080 households. The sample used in this study includes 4,406 households (both borrowers and non-borrowers) from across the country.

\section{IMPACT OF VF AND SGP PARTICIPATION ON ECONOMIC AND SOCIAL WELFARE}

\subsection{Microfinance Impact: PSM Impact Evaluation}

\subsubsection{Estimation Strategies}

The coefficient of the mean impact of treatment on $\delta_{P S M}^{A T T}$ is obtained by utilizing the PSM method, based on the following specification:

$\delta_{P S M}^{A T T}=E\left(y_{1} \mid T=1, x\right)-E\left(y_{0} \mid T=0, x\right)$

Where $y_{1}, y_{0}$ : are the potential outcomes of the two counterfactual situations (that is, participation vs nonparticipation in the microfinance program). The outcomes in this study are household monthly income and expenditure (measured in THB 1,000). $\mathrm{T}$ is a binary variable if a household participates in a microfinance program $(\mathrm{T}=1)$ or if not $(\mathrm{T}=0)$. $\mathrm{X}$ is a covariate set of observed characteristic variables. Household income and consumption in 2017 are also included in the covariate to explain the microfinance program impact estimator of each outcome of interest.

\subsubsection{Results and Discussion}

\section{VF Impact on Income and Expenditure (Housing, Food, Medicine, Education, and Transport)}

The estimates of the average treatment effect of VF program participation on the treated (ATT) are reported in Table 1 for six outcomes using nearest neighbor matching. According to these propensity score matching (PSM) estimates, the average income of VF borrowers is less than non-borrowers, by 3,037 baht. Moreover, on average borrowers spent 99 baht less on education, and 63 baht less on transport per month than their nonborrower counterparts. This comparison is based on data from 8,700 borrowers and 32,399 non-borrowers. Matching results are statistically significant at the 5\% level in income and educational expenditure, while transport expenditure is statistically significant at the $10 \%$ level. Housing, food, and medical expenditure are not statistically significant.

Table 1. Average Treatment Effect of VFs on Monthly Income and Expenditure using Matching Estimator

\begin{tabular}{lccc}
\hline & VF Participation & Control & Difference \\
\hline Mean Income & 18.5678454 & 21.6047457 & $-3.03690034 * *$ \\
& & $(1.24235013)$ \\
Mean Housing Expenditure & 1.97018333 & 2.09721264 & -0.12702931 \\
Mean Food Expenditure & & $(0.124667992)$ \\
\end{tabular}




\begin{tabular}{lccc}
\hline & VF Participation & Control & Difference \\
\hline Mean Medicine Expenditure & & & $(0.187204629)$ \\
& 0.333760345 & 0.308765402 & 0.024994943 \\
Mean Education Expenditure & & & $(0.06571221)$ \\
Mean Transport Expenditure & 0.160017586 & 0.259022069 & $-0.099004483 * *$ \\
& & & $(0.045000844)$ \\
& 0.121657701 & 0.184922874 & $-0.063265172 *$ \\
\hline
\end{tabular}

Note: $*, * *, * * *$ indicate significance at $10 \%, 5 \%$, and $1 \%$ levels, respectively.

Source: Author's calculations

\section{SGP Impact on Income and Expenditure (Housing, Food, Medicine, Education, and Transport)}

The estimates of the average treatment effect of SGPs program participation on the treated (ATT) are reported in Table 2 for six outcomes using nearest neighbor matching. According to these PSM estimates, the average income of SGPs borrowers is more than non-borrowers by 2,620 baht. The matching results are statistically significant at the 5\% level. This comparison is based on matching 6,035 borrowers and 35,064 non-borrowers. In terms of microfinance programs' impact on expenditure, the study results show that the SGP impact is insignificant. This finding indicates individuals or households participating in microfinance programs, have insignificant gains in terms of consumption over non-participants.

Table 2. Average Treatment Effect of SGPs on Monthly Income and Expenditure using Matching Estimator

\begin{tabular}{lccc}
\hline & SGP Participation & Control & Difference \\
\hline Mean Income & 36.4063407 & 33.7865327 & $2.61980795 * *$ \\
& & $(1.24857224)$ \\
Mean Housing Expenditure & 2.87622867 & 2.95109809 & $(-0.47)$ \\
& & -.074869428 \\
Mean Food Expenditure & 8.96191599 & 8.96929163 & $(.136074763)$ \\
Mean Medicine Expenditure & & .11216338 \\
Mean Education Expenditure & 0.6399657 & 0.52780232 & $(.095909038)$ \\
& & & -.046306711 \\
Mean Transport Expenditure & 0.452930903 & 0.499237614 & $(.038096793)$ \\
\hline
\end{tabular}

Note: $* * *, * * *$ indicate significance at $10 \%, 5 \%$, and $1 \%$ levels, respectively.

Source: Author's calculations

\subsection{Microfinance Impact: Impact Evaluation of Panel Data}

\subsubsection{Estimation Strategies}

To deal with the data problem, PSM is estimated for the first time to match borrowers with non-borrowers, using a set of observable characteristics. This estimation creates a new panel data set, which consists of borrower and non-borrower groups that have similar observed characteristics. The objective of this step is to eradicate observed heterogeneity in the initial period, before using the panel data model (Heckman, Ichimura, \& Todd, 1997). Panel data is used to solve unobserved variable bias when measuring the impact of VFs and SGPs because panel data can eliminate unobserved variable bias (Boonperm et al., 2013). This study uses the fixed effect model to evaluate the impact of VFs and SGPs in Thailand. Given the matched pre-program attributes from PSM and under the exogeneity of microfinance program participation, the microfinance program impact estimator can be obtained from equation (2). This model is given as follows:

$y_{i t}=\alpha_{i}+X_{i t} \beta+T_{i t} \gamma+\operatorname{YEAR}_{t} \varnothing+\varepsilon_{i t}$ 
Where $y_{i t}$ indicates the outcome variables of interest, for example, household income and consumption for household $i$ at time $t(t=2012,2017), X_{i t}$ is a set of regressors which are the observed household characteristics, $\mathrm{T}_{\mathrm{it}}$ is a program participation dummy variable which takes the value of 1 if individual or household $\mathrm{i}$ takes a loan from microfinance program in time $t$ and 0 otherwise. $Y_{E A R}$ is a vector of year dummy that takes into account time-specific effects, $\alpha_{\mathrm{i}}$ indicates unobserved characteristics of the household and $\varepsilon_{\mathrm{it}}$ are error terms.

\subsubsection{Results and Discussion}

\section{VF Impact on Income and Expenditure (Housing, Food, Medicine, Education, and Transport)}

VF participation does not affect borrowers' income and, with the exception of educational expenditure, all other forms of expenditure. This result indicates that VF participation does not help borrowers to improve their incomes or encourage them to spend more on food or healthcare. However, the VF can increase borrowers' educational expenditure. This result suggests that VF help some borrowers to invest in the education of their children.

Table 3. Fixed Effects with PSM Estimations for Income and Expenditure in VF Borrowers

\begin{tabular}{|c|c|c|c|c|c|c|}
\hline \multirow{2}{*}{ Variables } & \multirow{2}{*}{ Income } & \multicolumn{5}{|c|}{ Expenditure } \\
\hline & & Housing & Food & Medical & Educational & Transport \\
\hline \multicolumn{7}{|l|}{ Impact Estimator } \\
\hline VFs & -1.109376 & .0056216 & -.7136567 & .9818602 & $.5850309^{* * *}$ & -.1068905 \\
\hline \multicolumn{7}{|l|}{$\begin{array}{l}\text { Household Head } \\
\text { Characteristics }\end{array}$} \\
\hline Female $($ yes $=1$ ) & .677522 & $.3225577 * * *$ & .9450755 & $2.006114 * *$ & - & - \\
\hline Age (years) & - & - & - & - & -.0072381 & .0004469 \\
\hline Education (years) & $.4447149 * * *$ & -.0026981 & .0309014 & .1428451 & -.0281545 & $.1482071 * * *$ \\
\hline \multicolumn{7}{|l|}{ Demographics } \\
\hline Household Size (persons) & $3.793303 * * *$ & $.1599076^{* *}$ & $.8472188 * *$ & -.4009402 & $.2139098 * *$ & $.8647577 * * *$ \\
\hline Dependency Ratio & $-9.237941 * * *$ & $-.4888454 * * *$ & $-3.864304 * * *$ & $2.084671 *$ & .2545886 & $-.8382774 * *$ \\
\hline \multicolumn{7}{|l|}{ Occupations } \\
\hline Farmers (yes=1) & $-4.38953 * * *$ & $.1916534 *$ & -.0693813 & - & $.5073734 * *$ & -.0944817 \\
\hline Entrepreneurs (yes=1) & $-4.950402 * * *$ & .1856574 & .5476083 & .3972529 & $.7056456^{* * *}$ & .4435138 \\
\hline Formal Workers (yes=1) & $3.462766 * * *$ & $.2435397 *$ & $1.708603 * *$ & - & -.0048674 & .0253133 \\
\hline $\begin{array}{l}\text { Informal Workers } \\
(\text { yes }=1)\end{array}$ & $3.693892 * *$ & -.0526443 & .8465572 & .6651091 & $-1.370626 * * *$ & -.2099732 \\
\hline \multicolumn{7}{|l|}{ Assets } \\
\hline Assets & $-.0028307 * * *$ & $.0000999 * *$ & .0004177 & .0003287 & -.0000962 & $-.0002612^{* *}$ \\
\hline \multicolumn{7}{|l|}{ Other Variables } \\
\hline Year 2017 (yes=1) & -1.005088 & $-.1374717 * *$ & -.0672775 & $1.285281 * * *$ & $.5699771^{* * *}$ & $-.5326021 * * *$ \\
\hline Constant & -2.348395 & .016001 & 2.297775 & -1.396698 & -.6122521 & $-1.890575^{* *}$ \\
\hline Number of Observations & 3,279 & 3,279 & 3,279 & 3,279 & 3,279 & 3,279 \\
\hline
\end{tabular}

Note: $*, * * * *$ indicate significance at $10 \%, 5 \%$, and $1 \%$ levels, respectively.

Source: Author's calculations

SGP Impact on Income and Expenditure (Housing, Food, Medicine, Education, and Transport)

The result shows SGPs affect only income and transport expenses. This finding indicates that SGPs do not help borrowers to improve their housing or encourage borrowers to spend more on education, food or healthcare. 
However, the result suggests that SGPs loans can improve income and encourage borrowers to increase transport expenditure.

Table 4. Fixed Effects with PSM Estimations for Income and Expenditure in SGP Borrowers

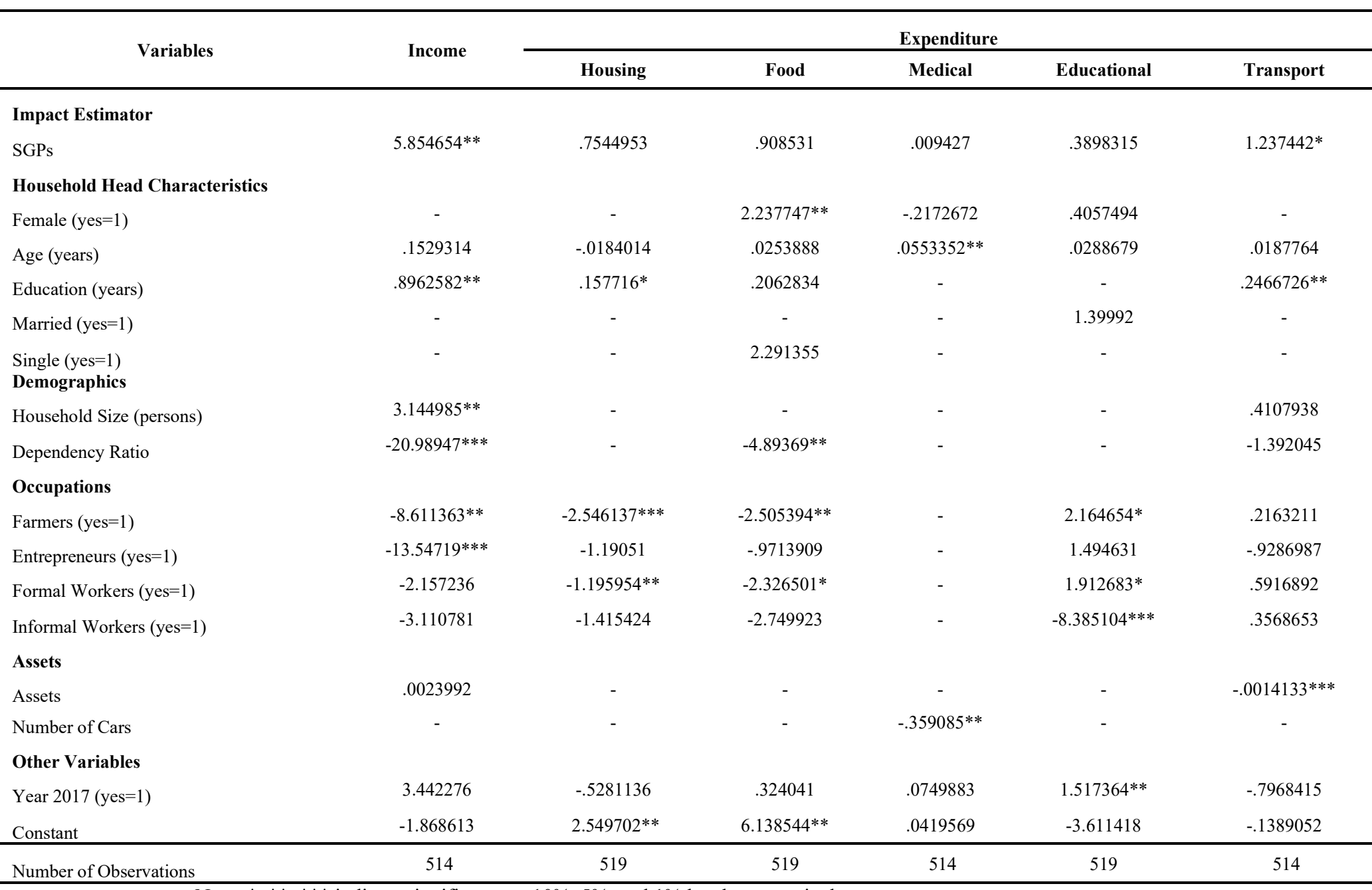

Note: $*, * *, * * *$ indicate significance at $10 \%, 5 \%$, and $1 \%$ levels, respectively.

Source: Author's calculations

\section{DISCUSSION AND CONCLUSIONS}

The PSM models estimate the welfare impacts of VF and SGP participation on income and expenditure. The impact of VFs are significant in terms of income, education, and transport expenditure but not on housing, food and medical expenditure. However, the sign of these variables is negative. This result indicates that VFs do not improve borrowers' wellbeing. VF borrowers spend their loans on non-consumption expenditure; in other words, VF borrowers do not spend loans on investment activities (Chandoevwit \& Ashakul, 2008). In addition, VF loans are not big enough to improve income and expenditure (Chandoevwit \& Ashakul, 2008). In terms of SGPs, the empirical results reveal that SGPs effects are significant in terms of income but not expenditure. This result indicates that SGP borrowers effectively invest their loans in income-generating activities, such as agricultural production and self-employment. PSM is a useful method for controlling bias due to observed determinants in impact evaluation; however, PSM cannot control for unobserved characteristics. Panel data can control for unobserved bias. This study utilizes the fixed effect model with PSM to evaluate the VF and SGPs impact on household income and expenditure. The results show that VF impacts only on educational expenditure: in other words, borrowers spend more money on education. Thai farmers in rural areas do not have much money during the planting season. If they have any expenses, such as children's school fees, they must borrow to pay these expenses. Our results suggest that the VF helps them to meet this particular need.

The fixed effect model with PSM also shows that SGPs affect income and transport expenditure. This result indicates that SGPs can improve borrowers' income and encourage borrowers to increase investment in 
working capital and assets. Moreover, SGPs' borrowers spend more on transport expenditure. Vehicles are necessary production inputs (Kaboski \& Townsend, 2012). Cars and motorcycles can help households to transport products from remote areas to their shops and markets. As MFI are designed to lend money for income generating activities, the very poor are unlikely to be granted loans. Microfinance programs will not be an effective solution; the extremely poor require both welfare and microfinance programs (Phan, 2012). Microfinance programs can only help the extremely poor once they have the necessary education. The government should provide social intermediaries for the poor, for example, education, job creation, physical infrastructure, and business skills to the poor to enable them to access to financial system (Hao, 2005). These policies would help the poor to participate in financial services (Hao, 2005). Microfinance programs need to do further work to identify who are the extremely poor and then make it a priority to help these individuals. Thai MFIs can use Central Public Database from the Revenue Department, Ministry of Finance, to identify poor people. The database is a personal income database which facilitates more effective targeting toward lowincome earners (NESDB,.2017). This strategy should help microfinance programs to reach the real poor who need the loans to improve their livelihoods and welfare.

\section{REFERENCES}

Asian Development Bank [ADB]. (2019). Poverty in Thailand. Retrieved from https://www.adb.org/countries/thailand/poverty

Bird, K., Hattel, K., Sasaki, E., \& Attapich, L. (2011). Poverty, income inequality, and microfinance in Thailand. Asian Development Bank. Retrieved from http://hdl.handle.net/11540/1311. License: CC BY 3.0 IGO.

Boonperm, J., Haughton, J., \& Khandker, S. R. (2013). Does the village Fund matter in Thailand? Evaluating the impact on incomes and spending. Journal of Asian Economics, 25, 3-16

Chandoevwit, W., \& Ashakul, B. (2008). The impact of the village fund on rural households. TDRI Quarterly Review, 23(2), 9-16.

Cintina, I., \& Love, I. (2014, September). The miracle of microfinance revisited: Evidence from Propensity Score Matching. University of Hawai'i at Manoa, Department of Economics, Working paper No. 14-24

Fongthong, S., \& Suriya, K. (2014). Determinants of Borrowers of the Village and Urban Community Fund in Thailand. CMUJ of Social Sciences and Humanities, 1(1), 21-37. doi: 10.12982/cmujASR.2014.0002

Hao, Q. M. (2005) Access to Finance and Poverty Reduction an Application to Rural Vietnam. (Unpublished doctoral thesis). University of Birmingham, Birmingham, England.

Heckman, J., Ichimura, H., \& Todd, P. (1997). Matching as an econometric evaluation estimator. Review of Economic Studies, 65, 261-294.

Kaboski, J. P., \& Townsend, R. M. (2012). The impacts of credit on village Economies. American Economic Journal: Applied Economics, 4(2), 98-133.

Luxchaigul, N. (2014). The effective of sustainable development of the saving for production groups in northeast of Thailand. Environment Management and Sustainable Development, 3(1), 168-180.

Meagher, P. (2013). Microfinance regulation and supervision recommendations report. Asian Development Bank.

Microfinance Services, Ltd. (2013). Thailand financial inclusion synthesis assessment report. Kingdom of Thailand: Development of a strategic framework for financial inclusion. Asian Development Bank. Retrieved from https://www.adb.org/sites/default/files/project-document/81802/45128-001-tacr-01-0.pdf

Office of the National Economic and Social Development Board [NESDB]. (2017). The twelfth national economic and social development plan (NESDP). Retrieved from https://www.nesdb.go.th/nesdb_en/ewt_w3c/ewt_dl_link.php?nid=4345

Suwaruchiporn, P. (2016, May). Financial inclusion in Thailand [PowerPoint]. Available from http://www.fsa.go.jp/en/glopac/20160519-1.pdf

Tambunlertchai, K. (2015). Financial inclusion, financial regulation, and financial education in Thailand. ADBI Working Paper 537. Tokyo: Asian Development Bank Institute. Retrieved from http://www.adb.org/publications/financial-inclusion-financial-regulation-financial-education-thailand/

Thailand Development Research Institution [TDRI]. (2004). Micro-banking development. Retrieved from http://www.info.tdri.or.th

The World Bank. (2019). World Bank open data. Retrieved from https://data.worldbank.org/

Warr, P. (2000). Is growth good for the poor? Thailand's boom and bust. International Journal of Social $\begin{array}{lllll}\text { Economics, } & 27 & (7-10), & 862-877 . & \text { Retrieved from }\end{array}$ http://econ.tu.ac.th/class/archan/Rangsun/EC\%20460/EC\%20460\%20Readings/Thai\%20Economy/Is\%20 Growth $\% 20$ Good $\% 20$ for $\% 20$ the $\% 20$ Poor.pdf 